\title{
Characteristics of unintentional ingestion of oral non- steroidal anti-inflammatory drugs and analgesics in preschool children
}

\author{
Željka Babić1 ${ }^{1}$ Nikolina Benco Kordić ${ }^{2}$, Arnes Rešić $^{2,3}$, and Rajka Turk ${ }^{1}$ \\ ${ }^{1}$ Institute for Medical Research and Occupational Health, Croatian Poison Control Centre, Zagreb, Croatia \\ ${ }^{2}$ Children's Hospital Zagreb, Department for Paediatric Clinical Pharmacology and Toxicology, Zagreb, Croatia \\ ${ }^{3}$ University of Split, University Department of Health Studies, Split, Croatia
}

[Received in October 2021; Similarity Check in October 2021; Accepted in December 2021]

\begin{abstract}
We characterised accidental ingestion of non-steroidal anti-inflammatory drugs and non-opioid analgesics in children aged $0-5$ years between 2009 and 2019 by analysing records of telephone consultations with the Croatian Poison Control Centre (CPCC) and cases treated at the Children's Hospital Zagreb (CHZ). Among the total of 466 identified cases (411 from CPPCC records and 55 from CHS hospital records), the most frequently ingested drugs were ibuprofen (47\%), paracetamol (20\%), ketoprofen $(15 \%)$, and diclofenac (11 \%). In $94 \%$ of the cases unsupervised children ingested the drug left within their reach. The remaining $6 \%$ were dosing errors by parents or caregivers and involved liquid formulations as a rule. Our findings can serve as real-life examples informing preventive measures.
\end{abstract}

KEY WORDS: diclofenac; ibuprofen; ketoprofen; NSAIDs; overdose; paracetamol; poisoning; toddlers

Due to wide use and unsafe storage non-steroidal antiinflammatory drugs (NSAIDs) and analgesics are frequent causes of poisoning in children. According to the last 2019 report issued by the Croatian Agency for Medicinal Products and Medical Devices (HALMED), consumption of antiinflammatory drugs had increased $8 \%$ a year in average between 2015 and 2019 (1). A recent survey of the Croatian Poison Control Centre (CPCC) has showed that around $75 \%$ of parents to preschool children tend to keep medications in their home "out of the reach of children" by their own estimation but not in child-proof compartments, and around one third sometimes keep various products, including medications, out of the original packaging (2). Fortunately, acute accidental ingestion of these medications rarely causes significant clinical effects in children. However, certain conditions (e.g. malnourishment or dehydration) associated with infective diseases commonly treated with NSAIDs and analgesic can aggravate their toxicity and lead to liver and kidney damage $(3,4)$.

Although some information about the frequencies of accidental ingestions of NSAIDs and analgesics in small children is available from epidemiological studies and annual reports of national poison information services (5-7), a detailed and long-term analysis focused on children is lacking. To address this gap, we decided to take a look at accidental exposure of preschool children (aged 0-5

Corresponding author: Željka Babić, Institute for Medical Research and Occupational Health, Croatian Poison Control Centre, Ksaverska cesta 2, 10000 Zagreb, Croatia, E-mail: zbabic@imi.hr years) to NSAIDs and non-opioid analgesics in Croatia between 2009 and 2019.

\section{METHODS}

\section{Data selection and extraction}

Our retrospective analysis included anonymised data from two sources: records from telephone consultations with the CPCC and hospital records of cases treated at the Department for Paediatric Clinical Pharmacology and Toxicology of the Children's Hospital Zagreb (CHZ). We searched for cases of unintentional exposure to NSAIDs and non-opioid analgesics involving children aged $0-5$ years in the period 2009-2019 (Figure 1). The search of CHZ hospital records and extraction of relevant nonidentifying personal data without the need of informed consent from parents was approved by CHZ's ethics committee (approval no. 02-23/32-1-20). On the other hand, patient information from CPCC consultations is recorded anonymously, so no ethical approval was sought for this part of the study.

From the records of both sources we extracted relevant data regarding patient demographics, circumstances of exposure, and clinical effects. However, here we present only clinical effects and doses ingested in symptomatic patients taken from complete $\mathrm{CHZ}$ medical records, as such information was not consistently available from CPCC telephone consultations. To calculate ingested doses in $\mathrm{mg} /$






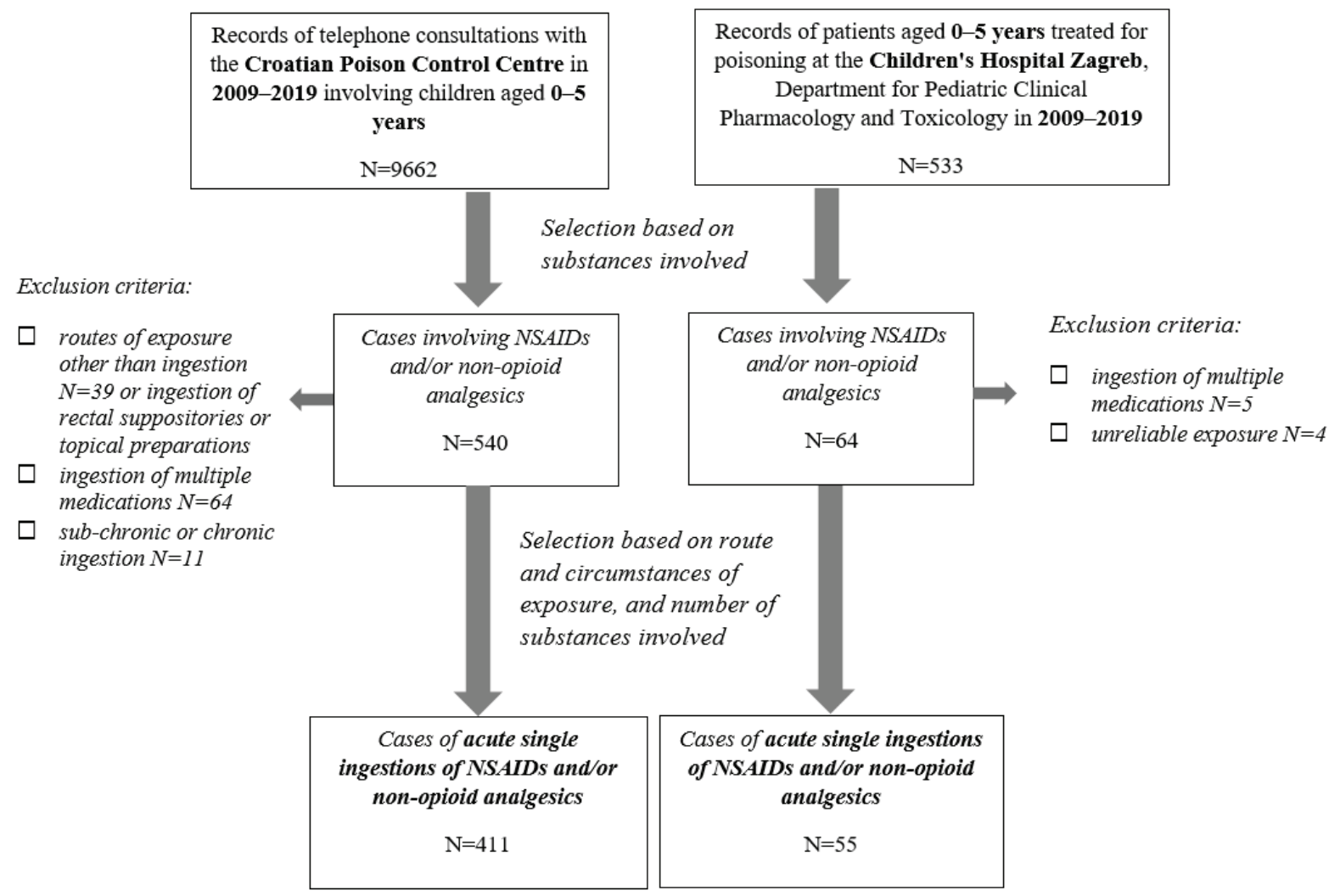

Figure 1 Data selection and extraction

$\mathrm{kg}$ in cases without reported body weight [ 89 of 340 CPCC cases with a reported dose and 31 of $47 \mathrm{CHZ}$ cases with reported dose], we took median body weight for reported age and sex from the World Health Organization's Child Growth Standards (8). To identify cases of overdose, we compared recorded and/or calculated doses with maximum daily doses (MDD) for ibuprofen $(30 \mathrm{mg} / \mathrm{kg})$ and paracetamol $(960 \mathrm{mg})$ published in the national register of medicines (9).

Ibuprofen doses above $200 \mathrm{mg} / \mathrm{kg}$ were considered to cause mild poisoning, and doses above $400 \mathrm{mg} / \mathrm{kg}$ to cause serious clinical symptoms (10). Paracetamol doses above $200 \mathrm{mg} / \mathrm{kg}$ were considered hepatotoxic (in children) (11), and we relied on the Rumack-Matthew nomogram available in Micromedex ${ }^{\circledR}$ toxicity database (Greenwood Village, Colorado, USA) (12) to characterise the risk of paracetamol hepatotoxicity in patients whose blood plasma levels were measured.

Cases of subchronic and chronic ingestions were excluded because repeated doses leading to clinical effects are usually lower than acute toxic doses. For example, acute doses of paracetamol above $200 \mathrm{mg} / \mathrm{kg}$ will probably lead to hepatotoxicity, in comparison to $150 \mathrm{mg} / \mathrm{kg}$ or more per 24-hour period for the preceding 48 hours, and $100 \mathrm{mg} / \mathrm{kg}$ or more per 24-hour period for the preceding 72 hours or longer. Due to different pharmacokinetic properties we also excluded cases of ingestions of formulations intended for other routes.

\section{Statistical analysis}

The extracted data were first analysed with descriptive statistics and then compared using the chi-squared or Fisher's test for categorical variables and the MannWhitney $U$ test for continuous variables. The associations were considered statistically significant at $p<0.05$. The analyses were run on the R Studio statistical software (Boston, MA, USA) (13).

\section{RESULTS}

Table 1 summarises the circumstances of accidental ingestion of single acute NSAID and analgesic doses in 466 preschool children in 2009-2019 (411 from CPCC records and 55 from CHS hospital records). No difference between the $\mathrm{CPCC}$ and $\mathrm{CHZ}$ cases was noted, except that $\mathrm{CHZ}$ patients were slightly older than the CPCC cases $(p<0.001$, Mann-Whitney $U$ test).

In 401 of the total 466 cases ( $86 \%$ ) the pharmaceutical form of the medication was known. In $161(40 \%)$ it was a liquid formulation such as an oral suspension or syrup, in $230(57 \%)$ an oral tablet or capsule, and in $10(2 \%)$ effervescent tablets or powders. Liquid forms dominated in cases of dosing errors by parents/caregivers (17 of 19 dosing errors). In terms of proportion, this was a significantly more common situation than with 144 of 382 unsupervised children ingesting a liquid form left within 
Table 1 Patient demographics and circumstances of exposure (2009-2019)

\begin{tabular}{lcc} 
& $\begin{array}{c}\text { CPCC cases } \\
(\mathbf{N}=\mathbf{4 1 1})\end{array}$ & $\begin{array}{c}\text { CHZ cases } \\
\text { (N=55) }\end{array}$ \\
\hline Age, median $(\mathrm{IQR})^{*}$ & $2.5(2.0-3.0)$ & $2.9(2.2-3.7)$ \\
\hline Male sex, N (\%*) & $188(46)$ & $32(53)$ \\
\hline Drug ingested, N (\%) & $191(46)$ & \\
\hline ibuprofen & $79(19)$ & $14(25)$ \\
paracetamol & $59(14)$ & $9(16)$ \\
ketoprofen & $44(11)$ & $5(9)$ \\
diclofenac & $22(5)$ & $1(2)$ \\
acetylsalicylic acid & $16(4)$ & - \\
\hline other** & & \\
\hline Circumstances of exposure & $386(94)$ & $54(98)$ \\
\hline unsupervised child ingested the drug left within reach & $25(6)$ & $1(2)$ \\
dosing error made by parents/caregivers & & \\
\hline
\end{tabular}

CPCC - Croatian Poison Control Centre; CHZ - Children's Hospital Zagreb; IQR - interquartile range; *in 17 CPCC cases age was not reported and in 55 CPCC cases sex was not reported; **other includes dextro-ketoprofen, flurbiprofen, meloxicam, metamizole, naclofen, naproxen, and piroxicam

their reach ( $89 \%$ vs $38 \%$, respectively; Fisher's exact test, $\mathrm{p}<0.001)$.

In the total study sample, the most frequent drugs ingested were ibuprofen (47\%), followed by paracetamol (20\%), ketoprofen (15\%), and diclofenac (11\%), with no significant difference between the CPCC and $\mathrm{CHZ}$ cases (Table 1). Ingested ibuprofen doses were above MDD $(30 \mathrm{mg} / \mathrm{kg})$ in 136 of 190 cases $(72 \%)$ with reported dose, while paracetamol doses were above the MDD $(960 \mathrm{mg})$ in 39 of 84 such cases (46\%). As expected, ingested ibuprofen and paracetamol doses above the MDD were significantly higher in $\mathrm{CHZ}$ than $\mathrm{CPCC}$ cases, and so was the proportion of symptomatic patients (Table 2). However, ingestion of a toxic dose above $200 \mathrm{mg} / \mathrm{kg}$ of either ibuprofen or paracetamol was reported in only three and two cases, respectively. Consequently, only minor gastrointestinal symptoms (vomiting, diarrhoea) and some laboratory abnormalities were noted with paracetamol (Table 2), but no elevated serum liver enzymes or liver function abnormalities. All of the three symptomatic $\mathrm{CHZ}$ patients with determined blood plasma paracetamol levels were at low risk of hepatotoxicity according to the RumackMatthew nomogram (12). More specifically, one patient had $53 \mu \mathrm{g} / \mathrm{mL}(351 \mu \mathrm{mol} / \mathrm{L}) 4 \mathrm{~h}$ after and $3 \mu \mathrm{g} / \mathrm{mL}$ $(20 \mu \mathrm{mol} / \mathrm{L}) 20 \mathrm{~h}$ after the estimated ingestion of $135 \mathrm{mg} /$ $\mathrm{kg}$ of paracetamol. The second patient had paracetamol levels below the limit of detection $[<0.26 \mu \mathrm{g} / \mathrm{mL}$ $(<2 \mu \mathrm{mol} / \mathrm{L})] 5 \mathrm{~h}$ after the estimated ingestion of $203 \mathrm{mg} /$ $\mathrm{kg}$, and the third patient had $12.59 \mu \mathrm{g} / \mathrm{mL}(83 \mu \mathrm{mol} / \mathrm{L})$ and $1.83 \mu \mathrm{g} / \mathrm{mL}(12 \mu \mathrm{mol} / \mathrm{L})$ four and $23 \mathrm{~h}$ after the ingestion of $155 \mathrm{mg} / \mathrm{kg}$, respectively.

Adverse effects of diclofenac in the dose range of 4-25 mg/kg included vomiting, drowsiness, apathy, hyperactivity, pallor, hypothermia, high serum lactate and calcium. With ketoprofen (in the dose range of 4-49 mg/ $\mathrm{kg}$ ), adverse effects included vomiting, facial flushing, high serum lactate, blood urea nitrogen, and acidosis. For naproxen $(43 \mathrm{mg} / \mathrm{kg})$ only vomiting was reported.
We also analysed gastric decontamination and treatment information in a subset of 344 CPCC patients on whose behalf a family or emergency physician or nurse consulted CPCC (median time to CPCC call was $40 \mathrm{~min}$, IQR $30 \mathrm{~min}$ $-1 \mathrm{~h}$ after ingestion). Twenty-seven ( $8 \%$ underwent gastric lavage, four of whom also received activated charcoal. Three patients received activated charcoal alone. Other information about symptomatic or supportive treatment was not available for this subset at the time of CPCC calls.

Among the $55 \mathrm{CHZ}$ patients, decontamination by gastric lavage and activated charcoal was done in 15 , while 16 received activated charcoal alone. Sixteen symptomatic patients [7 after ibuprofen, three after paracetamol (Table 2 ), three after diclofenac, and three after ketoprofen ingestions] received supportive treatment, but none required $\mathrm{N}$-acetylcysteine for paracetamol overdose. One patient who developed acidosis after ingestion of $45 \mathrm{mg} / \mathrm{kg}$ of ketoprofen received bicarbonates and fluid replacement (normal saline) by intravenous (iv) infusion. The rest received supportive care, mostly in the form of iv fluid replacement (eight patients), or iv infusion of a proton pump inhibitor (six patients).

\section{DISCUSSION}

Our findings call for better prevention of accidental NSAID and non-opioid analgesic ingestion by young children and can serve as real-life examples to inform preventive action. In the great majority (94\%) of cases, the drugs were left within their reach. This is not surprising, given that these medications are often not stored safely $(2$, $14,15)$ and that parents generally do not consider over-thecounter (OTC) medicines dangerous in terms of poisoning (16). Another unsafe habit contributing with up to $20 \%$ of poisonings in children is forgetting to put medication away immediately after use (17). 
Table 2 Profile of patients ingesting ibuprofen and paracetamol above maximum daily doses

\begin{tabular}{|c|c|c|c|c|}
\hline & \multicolumn{2}{|c|}{$\begin{array}{c}\text { Ibuprofen } \\
\text { (MDD } 30 \mathrm{mg} / \mathrm{kg} \text { ) }\end{array}$} & \multicolumn{2}{|c|}{$\begin{array}{l}\text { Paracetamol } \\
\text { (MDD } 960 \mathrm{mg} \text { ) }\end{array}$} \\
\hline & $\begin{array}{l}\text { CPCC cases } \\
(\mathrm{N}=121)\end{array}$ & $\begin{array}{l}\text { CHZ cases } \\
(N=15)\end{array}$ & $\begin{array}{l}\text { CPCC cases } \\
\qquad(\mathrm{N}=35)\end{array}$ & $\begin{array}{l}\text { CHZ cases } \\
(\mathrm{N}=4)\end{array}$ \\
\hline $\begin{array}{l}\text { Ingested dose in } \mathbf{~ m g / k g} \text {, } \\
\text { median (range) }\end{array}$ & $60(32-270)^{*}$ & $86(34-256)^{*}$ & $86(36-218)^{*}$ & $145(86-203)^{*}$ \\
\hline $\begin{array}{l}\text { Above toxic threshold of } \\
200 \mathrm{mg} / \mathrm{kg}, \mathrm{N}(\%)\end{array}$ & $2(2)$ & $1(7)$ & $1(3)$ & $1(25)$ \\
\hline Symptomatic, N (\%) & $7(6)^{*}$ & $7(47)^{*}$ & $1(3)$ & $3(75)$ \\
\hline $\begin{array}{l}\text { Doses in symptomatic } \\
\text { patients, median (range) }\end{array}$ & not investigated & $72(34-256)$ & not investigated & $145(135-155)$ \\
\hline \multicolumn{5}{|l|}{ Clinical effects, N (\%) } \\
\hline $\begin{array}{l}\text { vomiting } \\
\text { diarrhoea } \\
\text { abnormal laboratory findings }\end{array}$ & not investigated & $\begin{array}{c}3(20) \\
- \\
5(33)^{* *}\end{array}$ & not investigated & $\begin{aligned} & 2(50) \\
& 1(25) \\
& 2(50) * * *\end{aligned}$ \\
\hline
\end{tabular}

CPCC - Croatian Poison Control Centre; CHZ - Children's Hospital Zagreb; MDD - maximum daily dose calculated from the Croatian register of medicines (9). The toxic threshold for ibuprofen was set at $200 \mathrm{mg} / \mathrm{kg}$, above which gastrointestinal symptoms have been reported, and the threshold for serious adverse effects was set $400 \mathrm{mg} / \mathrm{mg}$. The toxic threshold for paracetamol was set at $200 \mathrm{mg} / \mathrm{kg}$, above which hepatotoxicity can be expected. Symptoms were investigated only in CHZ records, because they included all medical outcomes, while CPCC records included only the symptoms which occurred by the time of the telephone call. ${ }^{*} \mathrm{p}<0.001 ;{ }^{* *}$ serum alkalosis, elevated serum creatinine, elevated serum blood urea nitrogen, and elevated serum lactate; ***elevated serum lactate

Another possible scenario of unintentional exposure are dosing errors by parents or caregivers, as was the case in $6 \%$ of our cases. This is similar to the $8 \%$ reported in the USA for children aged $0-6$ years overdosed with paracetamol (18). Most of these dosing errors were associated with the liquid form, and only a few cases were owed to parents giving children tablets intended for adults. On the plus side, liquid forms were involved in only one third of unsupervised ingestions, which is about half of what was reported in an earlier study investigating ingestions of OTC drugs by children (19).

Although measures such as child-resistant packaging help to prevent serious poisoning (20-22), more effort is clearly needed to raise awareness that these products are appealing to children and that parents should check the dose carefully when administering liquid formulations.

Children in our study mostly overdosed with ibuprofen and paracetamol, which is in line with data from other countries (5-6). Although our primary focus was not on the symptoms of poisoning in relation to the ingested dose, our findings confirm that exploratory ingestions (which usually involve doses above MDD but below the toxic threshold of $200 \mathrm{mg} / \mathrm{kg}$ ) rarely lead to symptomatic poisoning. We draw this conclusion from the fact than no paracetamol hepatotoxicity was observed, which suggests that children ingested single doses below its toxic dose of $200 \mathrm{mg} / \mathrm{kg}$ (11).

It is interesting to note that doses of ibuprofen and paracetamol ingested by $\mathrm{CHZ}$ patients were significantly higher than those ingested by CPCC patients. This is expected, as parents/caregivers usually wait to see if there is any development with their child before they go a hospital and will sooner call a poison control centre for advice. Regarding other NSAIDs, the reported dose ranges of ketoprofen and diclofenac which were associated with symptomatic poisoning, predominately with gastrointestinal symptoms, contribute to the scarce evidence about toxic doses of these medications in children. In adults, a couple of grams of ketoprofen was associated with only minor effects (23).

In conclusion, since unintentional exposure of preschool children to NSAIDs and analgesics predominately occurred because the drug was left within their reach, more preventive effort is clearly needed to address this continuous problem of unsafe storage in Croatia. Our data should be used as a basis for planning preventive actions and as reallife cautionary messages. Also, given the fact that these exposures rarely lead to symptomatic poisoning, parents should be encouraged to first call their local/national poison control centre, emergency department, or their paediatrician to assess the option of home observation before seeking immediate medical attention. This could lower the burden on the healthcare system. On the other hand, it is important to refer to healthcare facility early after significant ingestions, and CPCC continues to support healthcare professionals with information on patient monitoring and treatment. We will continue to follow the situation, since unintentional exposure to substances available at home has increased during the COVID-19 pandemic (24).

\section{Conflicts of interest}

None to declare.

\section{REFERENCES}

1. Croatian Agency for Medicinal Products and Medical Devices. Potrošnja lijekova u Hrvatskoj 2015.-2019. [Drug 
consumption in Croatia 2015-2019, in Croatian] [displayed 3 December 2021]. Available at https://www.halmed.hr/ fdsak3jnFsk1Kfa/publikacije/Potrosnja-lijekova-uHrvatskoj-2015-2019.pdf

2. Babić Ž, Franić Z, Macan J. Keeping children safe from harmful household products: a survey on safety practices in Croatia. Arh Hig Rada Toksikol 2019;70:60-1. doi: 10.2478/ aiht-2019-70-3247

3. Kearns GL, Leeder JS, Wasserman GS. Acetaminophen overdose with therapeutic intent. J Pediatr 1998;132:5-8. doi: 10.1016/s0022-3476(98)70476-7

4. Misurac JM, Knoderer CA, Leiser JD, Nailescu C, Wilson AC, Andreoli SP. Nonsteroidal anti-inflammatory drugs are an important cause of acute kidney injury in children. J Pediatr 2013;162:1153-9. doi: 10.1016/j.jpeds.2012.11.069

5. Public Health England, National Poison Information Sevice. National Poisons Information Service Report 2017/18 [displayed 25 September 2020]. Available at https://www. npis.org/Download/NPISAnnualReport2017-18.pdf

6. Gummin DD, Mowry JB, Spyker DA, Brooks DE, Beuhler MC, Rivers LJ, Hashem HA, Ryan ML. 2018 Annual Report of the American Association of Poison Control Centers' National Poison Data System (NPDS): $36^{\text {th }}$ Annual Report. Clin Toxicol 2019;57:1220-413. doi: 10.1080/15563650.2019.1677022

7. Babić Ž, Turk R. Analysis of Croatian Poison Control Centre consultations involving poisonings in preschool children (2007-2016) as a basis for poisoning prevention action. In: Proceedings of $38^{\text {th }}$ International Congress of the European Association of Poisons Centres and Clinical Toxicologists (EAPCCT); 22-25 May 2018; Bucharest, Romania. Clin Toxicol 2019;56:557. doi: 10.1080/15563650.2018.1457818

8. World Health Organization. Child Growth Standards. Weightfor-age [displayed 20 September 2020]. Available at https:// www.who.int/childgrowth/standards/weight_for_age/en/

9. Udruga poslodavaca u zdravstvu Hrvatske. Registar lijekova u Hrvatskoj [Register of medications in Croatia, in Croatian]. Zagreb: Medicinska naklada; 2021.

10. Hall AH, Smolinske SC, Conrad FL, Wruk KM, Kulig KW, Dwelle TL, Rumack BH. Ibuprofen overdose: 126 cases. Ann Emerg Med 1986;15:1308-13. doi: 10.1016/s01960644(86)80617-5

11. Dart RC, Erdman AR, Olson KR, Christianson G, Manoguerra AS, Chyka PA, Caravati EM, Wax PM, Keyes DC, Woolf AD, Scharman EJ, Booze LL, Troutman WG; American Association of Poison Control Centers. Acetaminophen poisoning: an evidence-based consensus guideline for out-of-hospital management. Clin Toxicol 2006;44:1-18. doi: 10.1080/15563650500394571
12. Micromedex ${ }^{\circledR}$ (electronic version). IBM Watson Health, Greenwood Village, Colorado, USA [displayed 1 September 2020]. Available at https://www.micromedexsolutions.com/

13. RStudio Team. Integrated Development for R. RStudio, 2019. USA [displayed 1 September 2020]. Available at http://www. rstudio.com

14. Gutierrez J, Negrón J, García-Fragoso L. Parental practices for prevention of home poisoning in children 1-6 years of age. J Community Health 2011;36:845-8. doi: 10.1007/ s10900-011-9384-4

15. Hawkins ER, Brice JH, Overby BA. Welcome to the world: findings from an emergency medical services pediatric injury prevention program. Pediatr Emerg Care 2007;23:790-5. doi: 10.1097/PEC.0b013e318159ffd9

16. Rosenberg M, Wood L, Leeds M, Wicks S. "But they can't reach that high...": parental perceptions and knowledge relating to childhood poisoning. Health Promot J Austr 2011;22:217-22. doi: 10.1071/he11217

17. Kendrick D, Majsak-Newman G, Benford P, Coupland C, Timblin C, Hayes M, Goodenough T, Hawkins A, Reading R. Poison prevention practices and medically attended poisoning in young children: multicentre case-control study. Inj Prev 2017;23:93-101. doi: 10.1136/ injuryprev-2015-041828

18. Angalakuditi MV, Coley KC, Krenzelok EP. Children's acetaminophen exposures reported to a regional poison control center. Am J Health Syst Pharm 2006;63:323-6. doi: 10.2146/ajhp050227

19. Schoenewald S, Ross S, Bloom L, Shah M, Lynch J, Lin CL, Patel M, Boyle K, Kuffner E. New insights into root causes of pediatric accidental unsupervised ingestions of over-thecounter medications. Clin Toxicol 2013;51:930-6. doi: $10.3109 / 15563650.2013 .855314$

20. Rodgers GB. The effectiveness of child-resistant packaging for aspirin. Arch Pediatr Adolesc Med 2002;156:929-33. doi: 10.1001/archpedi.156.9.929

21. Paul IM, Reynolds KM, Delva-Clark H, Burnham RI, Green JL. Flow restrictors and reduction of accidental ingestions of over-the-counter medications. Am J Prev Med 2019;56:e205-13. doi: 10.1016/j.amepre.2018.12.015

22. Brass EP, Reynolds KM, Burnham RI, Green JL. Frequency of Poison Center exposures for pediatric accidental unsupervised ingestions of acetaminophen after the introduction of flow Restrictors. J Pediatr 2018;198:254-9. e1. doi: 10.1016/j.jpeds.2018.02.033

23. Miller AH. Overdose of slow release ketoprofen. NZ Med J 1990;103:282. PMID: 2356064

24. Babić Ž, Turk R, Macan J. Toxicological aspects of increased use of surface and hand disinfectants in Croatia during the COVID-19 pandemic: a preliminary report. Arh Hig Rada Toksikol 2020;71:261-4. doi: 10.2478/aiht-2020-71-3470 


\section{Karakterizacija nenamjerne izloženosti predškolske djece nesteroidnim protuupalnim lijekovima i neopioidnim analgeticima}

Istražili smo nenamjernu izloženost djece u dobi do pet godina nesteroidnim protuupalnim lijekovima i neopioidnim analgeticima u razdoblju 2009.-2019., analizirajući ne samo zapise telefonskih konzultacija s hrvatskim Centrom za kontrolu otrovanja (CKO), čija služba za savjetovanje u slučaju otrovanja pokriva cjelokupno hrvatsko stanovništvo, nego i dokumentaciju pacijenata liječenih u Klinici za dječje bolesti Zagreb (KDB), u koju se obično upućuju slučajevi otrovanja. Ukupno je identificirano 466 slučajeva (411 iz evidencije CKO-a i 55 iz bolničke evidencije KDB-a). U ukupnom uzorku, najčešće se radilo o ingestiji ibuprofena (47\%), zatim paracetamola $(20 \%)$, ketoprofena $(15 \%)$ i diklofenaka (11\%). Sveukupno, u 94 \% slučajeva dijete koje je bilo ostavljeno bez nadzora, progutalo je lijek koji mu je bio nadohvat ruke. Ostatak (6\%) bio je posljedica pogrešaka roditelja ili njegovatelja u doziranju. Tekuće formulacije bile su uključene u gotovo sve slučajeve pogrešaka u doziranju (89 \%). Naši bi se rezultati trebali koristiti kao primjeri iz stvarnog života koji daju važnost preventivnim savjetima.

KLJUČNE RIJEČI: diklofenak; dojenčad; ibuprofen; ingestija; ketoprofen; NSAID; otrovanje; predoziranje; paracetamol 